\title{
PURCHASING POWER PARITY (PPP) BETWEEN CHINA AND THE U.S.: AN EMPIRICAL COMPARATIVE CASE STUDY
}

\section{DOI: 10.17261/Pressacademia.201519949}

\author{
Murat GIDIS', Fatih MANGIR², Hasan Murat ERTUGRUL ${ }^{3}$, Bansi SAWHNEY ${ }^{4}$ \\ ${ }^{1}$ Energy Market Regulatory Authority. E-mail: mgidis@epdk.org.tr \\ ${ }^{2}$ Selçuk University. E-mail: fmangir@selcuk.edu.tr \\ ${ }^{3}$ Republic of Turkey Prime Ministry Undersecretariat of Treasury. E-mail: murat.ertugrul@hazine.gov.tr \\ ${ }^{4}$ University of Baltimore. E-mail: bsawhney@ubalt.edu
}

\section{Keywords:}

Yuan-Dollar Exchange Rates, PPP Hypothesis, Unit Root Tests, Fixed and Managed Floating Exchange Rate Regime

\section{JEL Classification:}

$\mathrm{F} 31, \mathrm{C} 22$

\begin{abstract}
This study investigates the validity of Purchasing Power Parity (PPP) in explaining China's real exchange rate with regard to the US over the period 2000-2012. It applies traditional unit root tests, and the procedure developed by Zivot and Andrews and Lee-Strazicich to endogenously determine potential structural breaks. The results indicate that while the PPP hypothesis holds under China's former fixed ("pegged") exchange regime, that, in the long run, it no longer holds under China's current managed floating exchange rate regime. In general, the findings lend support to the position that the exchange rate regime affects the validity of PPP theory for explaining exchange rates between countries.
\end{abstract}

\section{INTRODUCTION}

The mounting deficits in the trade between the U.S. and China trade have raised mounting concern in the U.S. over the yuan-dollar exchange rate. Many U.S. economists and policy makers are asking questions relating to China's exchange rate policy. In international economic theory, the determination of equilibrium real exchange rate is a key economic concept. It gains special importance during peiods of currency crisis. Although there are a number of different methodologies to assess equilibrium exchange rates, ${ }^{[1]}$ the purchasing power parity (PPP) hypothesis is one of the most studied in determining exchange rates in the economic literature. The topic of "PPP" was first introduced 85 years ago by the Swedish economist Gustav Cassel (Cassel, 1918). It has gained in popularity among economists ever since. Theoretically, PPP, based on the relative price levels between countries, has been generally accepted as the main theory of long-term equilibrium exchange rates. In its most common form, it asserts that changes in the exchange rate change between two currencies over the period of time is determined by the changes in the two countries domestic relative price levels (Dornbusch, 1985:1). When PPP holds continuously over time for two countries, then the volatility of the nominal exchange rate between countries will be no greater than the volatility of relative national prices (Taylor, 2003:438). 
According to the Purchasing Power Parity (PPP), exchange rates and prices should adjust such that goods in different countries have the same price when expressed in the same currency (Absolute PPP). Relative PPP states that the percentage depreciation in the exchange rate between two currencies over any period equals the difference between inflation rates in the home country and in the foreign country. In the (very) long run changes in nominal exchange rates should reflect differences in inflation as predicted by relative PPP. The rationale of PPP depends on perfect arbitrage. Hence, from the empirical point of view, PPP is likely not to hold in the short run (Aizenman, 1984; Rogers and Jenkins, 1995).

The type of exchange rate regime in a country also affects the determining power of national price levels on exchange rates. Mussa (1986) argued that the real exchange rate volatility depends on the exchange rate regime adopted. From the early years of the transition until the current float, several empirical studies also have found that PPP failed to hold continuously due to high exchange rate volatility (Rogoff, 1996). One way, as suggested in this paper is, to examine the long-run validity of PPP is to test the hypothesis of stationary real exchange rate.

The purpose of this paper is to re-examine long-run purchasing power parity between the Chinese Yuan and the U.S. dollar. We apply stationarity tests on real exchange rates. PPP holds in the long-run if the real exchange rate is stationary. The most popular price and costs measures used are consumer prices (CPI), producer prices (PPI), GDP deflator, unit labor costs (ULC) ${ }^{[2] . ~ S e v e r a l ~ p r e v i o u s ~ w o r k s ~ h a v e ~ t e s t e d ~ P P P ~ w i t h ~ r e a l ~ e x c h a n g e ~ r a t e ~ d a t a ~}$ constructed from nominal exchange rates and national price levels measured by consumer prices indexes (CPI). But, some of the measurement problems that have been encountered when testing PPP center on the use of these price indexes. Different countries weight their goods differently when measuring price changes, so that even choosing a different base year will yield different weights (Craig, 2005). We attempt to fill this gap in the literature by examining PPP with rescaled real bilateral exchange rates for two different types of exchange rate systems in China ${ }^{[3] .}$

This paper extends the empirical literature on Chinese PPP in three ways. First, we test for PPP for the Chinese yuan versus the US dollar rescaled real bilateral exchange rates. Secondly, we conduct a wide variety of unit root tests, including those that allow structural breaks. Third, we investigate the validity of PPP for two different types of exchange rate systems in China.

\section{LITERATURE REVIEW}

Over the last eighty years, numerous attempts have been made to test statistically whether or not the PPP theory holds. The majority of the empirical studies used data from the industrial developed countries with the dollar exchange rate being the most common rate analyzed. While studies that used very long sample periods provide some support for the existence of PPP, research that focused on shorter periods of time tended to find significant disparities between relative prices and exchange rates. (See Dornbusch 1992:236-244; Breuer 1994:245-277; and Rogoff 1996:647-668 for overviews of PPP research). 
By far, there have been only a few emprical studies to test the validity of long-run purchasing power parity in China and the U.S.

The most recent studies include Darne and Hoarau (2006) examined the validity of longrun purchasing power in China for the period 1970:1 to 2006:5 using outlier methodology and showed that there is no tendency to the purchasing power parity in China to hold in the long run during this period. Waithe (2010) investigated the existence of PPP by means of a US-China case study and a cross-country analysis of 79 countries across different continents with varying economic status using monthly data from January 1994 to August 2009. He rejected the PPP hypothesis in the US-China case study, but supported the PPP hypothesis under the cross country analysis.

$\mathrm{Yu}$ and Zhu (2010) assessed the RMB exchange rate based on the monthly data of RMB/USD nominal exchange rate, Chinese Consumer Price Index (CPI) and the US CPI from May 1994 to December 2006. The results indicate that the 'strict' relative PPP doesn't hold while the 'weak' one (regression analysis) holds for RMB/USD exchange rate, which suggests that the variation of RMB/USD exchange rate has a tendency of reverting to the PPP level in terms of 'strict' relative PPP.

Guo (2010) applied time series and panel cointegration tests to both the official and the black market exchange rates in China over the period 1985-2006, and concluded that the real exchange rate in China is inconsistent with the long run PPP hypothesis in traded goods for both black market and official markets.

Several other studies used different methodologies. For example, Gil-Alana and Jiang (2011) employed fractional integration techniques to test the PPP hypothesis in the US/China relationship over the sample period 1994M01 to 2010M11. They found that there is no mean reversion for the real exchange rate between China and U.S. across the whole sample period.

Gregory and Shelley (2011) also found results from unit root tests that bilateral China U.S. real exchange rate do not support purchasing power parity between the two countries. However, tests of the real equivalent exchange rate for the Chinese yuan versus a traded-weighted basket of currencies support purchasing power parity.

Giannellis and Kouretas (2012) have employed the linear and nonlinear unit root tests to investigate whether the adopted exchange rate policy can lead to the achievement of equilibrium in the foreign exchange market. They found that PPP equilibrium could not be established in periods of the fixed exchange rate regime.

\section{METHODOLOGY}

Formalized by Cassel (1918), the real Exchange (RER) rate can be defined in equation 1 :

$$
R E R=E P^{*} / P
$$

where $\mathrm{E}$ denotes the nominal exchange rate (measured as domestic currency price of foreign currency), $P^{*}$ is an index of the foreign price level, and $P$ is an index of the domestic price level.

Denoting logarithms in lower case letters, we therefore have equation 2. 


$$
r=e+p-p^{*}
$$

" $r$ " defines logarithmic form of real exchange rate and " $p$ *" and " $p$ " denote the logarithms of the domestic and foreign country price index respectively.

The validity of long-run PPP requires the stationarity of real exchange rates. If $r$ is stationary then deviations from PPP are temporary and will disappear with time, and hence PPP is likely to hold in the long run. But if " $r$ " has a unit-root, then it implies that deviations from the parity are cumulative and not ultimately self-reverting.

This study aims to investigate stationarity properties of the real bilateral exchange rate of China employing both conventional unit root tests and unit root tests with structural breaks. In order to investigate stationary properties of the RER series, we employed conventional unit root tests including ADF (Dickey and Fuller, 1981), PP (Phillips-Perron, 1988), KPSS (Kwiatkowski, Phillips, Schmidt, and Shin, 1992) and Ng-Perron tests (2001) and unit root tests with structural breaks including Zivot-Andrews (1992 and Lee and Strazicich (2003) tests.

Empirical works based on time series data assume that the underlying time series is stationary. A stochastic process is said to be stationary if its mean and variance are constant over time and the value of the covariance between the two time periods depends only on the distance or gap or lag between the two time periods and not the actual time at which the covariance is computed (Gujarati, 2004). Stationary series exhibits mean reversion in that it fluctuates around a constant long-run mean and has a finite variance that is time invariant. On the other hand, a nonstationary series has no long run mean to which series returns and the variance is time dependent and goes infinity as time approaches infinity (Enders, 2004).

The most commonly used conventional unit root tests in empirical studies are ADF, PP and KPSS tests. However, the ADF, PP and KPSS tests have some limitations and may lead to a misleading conclusion (Silvia and Iqbal, 2011) ${ }^{[4] .}$

Ng and Perron (2001) introduced four unit root test statistics that are calculated using generalized least squares (GLS) de-trended data for a time series variable to deal with the constraints of ADF and PP unit root tests. Compared to widely used Dickey Fuller (DF) and Philips Perron (PP) unit root tests, that has better power and size properties (Wickremasinghe, 2006)

The main criticism of testing PPP is based on the deficiency of conventional unit root tests that they are assumed to be temporary shocks that have no long-run effect on a variable. It is also recognized that the outliers and breaks in data may lower the power of unit root tests and lead toward over-acceptance of the unit-root hypothesis (Zhou and Kutan, 2011). Employing unit root tests with structural breaks for RER is one way of resolving conventional unit root tests failure. In that respect, we employ Zivot-Andrews (1992) test with one-break and Lee and Strazicich (2003) tests with two-breaks for the existence of unit roots and identify the order of integration for each variable. 
The endogenous structural break test of Zivot and Andrews (1992) is a sequential test which utilizes the full sample and uses a different dummy variable for each possible break date (Byrne and Perman, 2006). They consider all three possible ways that a structural break can appear in a time series as Perron 1989.

Zivot and Andrews (1992) consider three different models (Models A, B and C) for the unit root test equation. Null hypothesis of unit root for these three models is same and shown in equation 3.

$$
H_{0}: Y_{t}=\mu+Y_{t-1}+e_{t}
$$

Alternative hypothesis against null hypothesis of unit root is shown for every model in equation 4-6.

Model A

$$
Y_{t}=\hat{\mu}^{A}+\hat{\theta}^{A} D U_{t}(\hat{\lambda})+\hat{\beta}^{A} t+\hat{a}^{A} Y_{t-1}+\sum_{j=1}^{k} \hat{c}_{j}{ }^{A} \Delta y_{t-j}+e_{t}
$$

Model B

$$
Y_{t}=\hat{\mu}^{B}+\hat{\beta}^{B} t+\hat{\gamma}^{B} D T_{t}^{*}(\hat{\lambda})+\hat{a}^{B} Y_{t-1}+\sum_{j=1}^{k} \hat{c}_{j}{ }^{B} \Delta y_{t-j}+e_{t}
$$

Model C

$$
Y_{t}=\hat{\mu}^{C}+\hat{\theta}^{C} D U(\hat{\lambda})+\hat{\beta}^{C} t+\hat{\gamma}^{C} D T_{t}^{*}(\hat{\lambda})+\hat{a}^{C} Y_{t-1}+\sum_{j=1}^{k} \hat{c}_{j}{ }^{C} \Delta y_{t-j}+e_{t}
$$

(6)

where $D U_{t}(\hat{\lambda})$ is dummy variable and shows break in constant and $D U_{t}(\hat{\lambda})$ $=1$ if $t \succ T . \lambda$ i, 0 otherwise; $D T_{t}^{*}(\hat{\lambda})$ is dummy variable and shows break in trend and $D T_{t}^{*}(\hat{\lambda})=t-T . \lambda$ if $t \succ T . \lambda$ and 0 otherwise. Also; $T_{B}$ shows break time and, $\lambda=T_{B} / T$ shows break point.

The critical values in Zivot and Andrews (1992) are different compared to the critical values in Perron (1989). The difference is due to that the selection of the time of the break is treated as the outcome of an estimation procedure, rather than predetermined exogenously (Glynn, Perera and Verma, 2007). According to Zivot-Andrews (1992) tests, the null hypothesis shows that the series have unit root. If the calculated t statistics for variables are greater than the critical values in their level forms, we reject null hypothesis of unit root and we say the variables are trend stationary. Otherwise we couldn't reject null hypothesis of unit root. 
Lee and Strazicich's (2003) model allows for two endogenous breaks both under the null and the alternative hypothesis. They indicates that the two-break LM unit root test statistic estimated by employing LM test will not spuriously reject the null of a unit root. (Glynn, Perera and Verma, 2007).

Unlike from Zivot and Andrews (1992), Lee-Strazicich (2003) test uses Model A and Model C. For Lee-Strazicich (2003) test, Model A shows two breaks in constant and shown in equation 7.

$$
\begin{aligned}
& Y_{t}=\delta^{\prime} Z_{t}+e_{t}, e_{t}=\beta e_{t-1}+\varepsilon_{t} \\
& Z_{t}=\left[1, t, D_{1 t}, D_{2 t}\right]
\end{aligned}
$$

Where $Z_{t}$ is exogenous variables vector and $T_{B j}$ show break date. $J=1,2, \ldots$ if $t \succ T_{B j} D_{j t}=1$ and 0 otherwise.

Model $\mathrm{C}$ shows two breaks in constant and trend and shown in equation 8;

$$
\begin{aligned}
& Y_{t}=\delta^{\prime} Z_{t}+e_{t}, e_{t}=\beta e_{t-1}+\varepsilon_{t} \\
& Z_{t}=\left[1, t, D_{1 t}, D_{2 t}, D T_{1 t}, D T_{2 t}\right]^{\prime}
\end{aligned}
$$

In equation (8) $J=1,2, \ldots$ if $t \succ T_{B j}+1 D T_{j t}=t$ and 0 otherwise (Lee and Strazicich, 2003). Critical values are computed by Lee-Strazicich (2003).

According to test results, if the calculated t statistics for variables are greater than the critical values in their level forms, we reject null hypothesis of unit root with structural break and we say the variables are trend stationary. Otherwise we couldn't reject null hypothesis of unit root with structural break.

\section{DATA AND EMPRICAL RESULTS}

In this study, we used real bilateral real exchange rates to test PPP for U.S. and China for the period 2000-2012. The exchange rate of the yuan was pegged constantly to the U.S. dollar until the middle of 2005. Since then, China adopted a managed floating exchange rate system. To test purchasing power parity under different exchange rate regime, we separated the analysis into two period: Fixed 2000: Month (M) 1-2005:M7 and Managed: 2005 M8 - 2012M2.

Nominal US dollar and Yuan exchange rates and CPI series were obtained from St. Louis FED, Electronic Data Delivery System. Real bilateral exchange rate series for Yuan/US dollar are denoted as BER. BER are weighted averages of bilateral exchange rates adjusted by relative consumer prices. The weighting pattern is time-varying, and the weights are based on trade in 2000-12. In order to investigate stationarity characteristics of BER series, we employ both conventional unit root tests including ADF (1979), PP (1988), KPSS (1992) and Ng-Peron (2001) tests and unit root tests with structural breaks including Zivot-Andrews (1992) test with one-break and Lee and Strazicich (2003) tests with two-breaks. 


\subsection{Results from Fixed Exchange Rate Regime: 2000 M1 - 2005M6}

The results of conventional stationary tests are presented in Table 1.

Table 1: Conventional Unit Root Test Results

\begin{tabular}{|c|c|c|c|c|c|}
\hline \multicolumn{6}{|c|}{ ADF Test Results } \\
\hline BER & \multicolumn{2}{|l|}{$-3.862^{* *}$} & & & \\
\hline \multicolumn{3}{|c|}{$\begin{array}{l}\text { ADF critical values for BER } \\
\% 1=-4.106 \text { and } \% 5=-3.480\end{array}$} & & & \\
\hline \multicolumn{6}{|c|}{ PP Test Results } \\
\hline BER & \multicolumn{2}{|l|}{-2.565} & \multicolumn{2}{|l|}{$\triangle \mathrm{BER}$} & $-6.176^{*}$ \\
\hline \multicolumn{3}{|c|}{$\begin{array}{l}\text { PP critical values for BER } \\
\% 1=-4.103 \text { and } \% 5=-3.479\end{array}$} & \multicolumn{3}{|c|}{$\begin{array}{l}\text { PP critical values for } \triangle B E R \\
\% 1=-2.601 \text { and } \% 5=-1.946\end{array}$} \\
\hline \multicolumn{6}{|c|}{ KPSS Test Results } \\
\hline BER & \multicolumn{2}{|l|}{0.231} & \multicolumn{2}{|c|}{$\triangle \mathrm{BER}$} & $0.040 *$ \\
\hline \multicolumn{3}{|c|}{$\begin{array}{l}\text { KPSS critical values for BER } \\
\% 1=0.216 \text { and } \% 5=0.146\end{array}$} & \multicolumn{3}{|c|}{$\begin{array}{l}\text { KPSS critical values for } \triangle B E R \\
\% 1=0.216 \text { and } \% 5=0.146\end{array}$} \\
\hline \multicolumn{6}{|c|}{ Ng-Perron Test Results } \\
\hline & $M Z_{a}$ & $M Z_{t}$ & & MSB & MPT \\
\hline BER & -11.392 & -2.368 & & 0.208 & 8.095 \\
\hline$\triangle \mathrm{BER}$ & -23.475 & -3.418 & & 0.146 & \begin{tabular}{l|l}
1.070 \\
\end{tabular} \\
\hline $\begin{array}{l}\mathrm{Ng}-\mathrm{Pe} \\
1 \% \mathrm{si} \\
5 \% \mathrm{~s} \\
\mathrm{Ng}-\mathrm{Pe} \\
1 \% \mathrm{si} \\
5 \% \mathrm{~s} \\
* \quad \mathrm{de}\end{array}$ & $\begin{array}{l}\text { I values for } \\
\text { level }-23.80 \\
\text { level }-17.3 \\
\text { I values for } \\
\text { level }-13.8 \\
\text { level for }-8 \\
\text { gnificance }\end{array}$ & $\begin{array}{l}\text { MZa, M } \\
.420,0 . \\
.910,0 . \\
R ; M Z a, \\
580,0 . \\
-1.980 \text {, } \\
* * \text { den }\end{array}$ & $\begin{array}{l}\text { Zt, MSt } \\
143 \text { anc } \\
168 \text { an } \\
\text { MZt, M } \\
174 \text { anc } \\
0.233 \\
\text { ote } 59\end{array}$ & $\begin{array}{l}\text { MPT res } \\
.030 \\
5.480 \\
3, \text { MPT r } \\
.780 \\
d 3.170 \\
\text { ignifica }\end{array}$ & $\begin{array}{l}\text { ctively; } \\
\text { evel }\end{array}$ \\
\hline
\end{tabular}

According to Table 1,

- For ADF test the null hypothesis suggests that the series include unit root. The calculated $t$ statistics for BER series is greater than the critical values at $5 \%$ significance level. Thus, the null unit roots hypothesis can be rejected, suggesting that BER is stationary in their level forms according to ADF test.

- For PP test, the null hypothesis suggests that the series include unit root. The calculated $t$ statistics for BER is less than the critical values. Thus, the null unit roots hypothesis cannot be rejected, suggesting that all variables are non-stationary in their level forms. The results of the first differenced variable show that PP test statistics for the variable is greater than critical values at $1 \%$ levels and the variable is stationary after differenced, suggesting that the variable is integrated of order I(1) according to PP test. 
- For KPSS test, the null hypothesis shows that investigated series is stationary. The calculated t statistics for BER is greater than the critical values in their level forms and the results of the first differenced BER variable is less than critical values at $1 \%$ levels. KPSS test results suggest that BER series is I(1).

- For Ng-Peron test, according to, MZa and MZt tests the null hypothesis shows that the series have unit root and according to MSB and MPT tests the null hypothesis shows that the series are stationary. For MZa and MZt tests, the calculated t statistics for all variables are less and for MSB and MPT tests the calculated $t$ statistics for all variables are greater than the critical values suggesting that all variables are non-stationary in their level forms. For the first difference of series, according to MZa and MZt tests, the calculated t statistics for the BER is greater and for MSB and MPT tests the calculated t statistics for the variable is less than the critical values at $1 \%$ levels suggesting that BER becomes stationary after differencing so that BER variable is $I(1)$ according to Ng-Peron tests.

The results of unit root tests with structural breaks are presented in Table 2.

Table 2: Unit Root Tests with Structural Breaks

\begin{tabular}{|l|l|l|}
\hline \multicolumn{2}{|l|}{ Zivot-Andrews (1992) Test Results } \\
\hline & Level & Model C \\
\hline & Model A & -5.58 \\
\hline BER & -5.41 & -5.08 \\
\hline Critical values (\%5) & -4.80 & $2003 \mathrm{M} 8$ \\
\hline Break Term & $2002 \mathrm{M} 2$ & \\
\hline Lee-Strazitch (2003) Test Results \\
\hline \multicolumn{2}{|l}{} \\
\hline & Level & Model C \\
\hline BER & Model A & -5.94 \\
\hline Critical values (\%5) & -3.89 & -5.71 \\
\hline
\end{tabular}

- According to both Zivot-Andrews (1992) and Lee-Strazicich (2003) tests, the null hypothesis shows that BER has unit root. For both Zivot-Andrews (1992) and LeeStrazicich (2003) tests, the calculated t statistics for BER variable is greater than the critical values in their level forms. Moreover both Zivot-Andrews (1992) and Lee-Strazicich (2003) tests suggest that BER variable is stationary in their level forms. 
In summary; according to all conventional unit root tests except ADF, BER series is I(1). However, unit root tests with structural breaks shows that BER series is stationary in their level forms.

4.2. Results from Managed Exchange Rate Regime: 2005 M7 - 2012M2

The results of conventional stationary tests are presented in Table 3.

Table 3: Conventional Unit Root Test Results

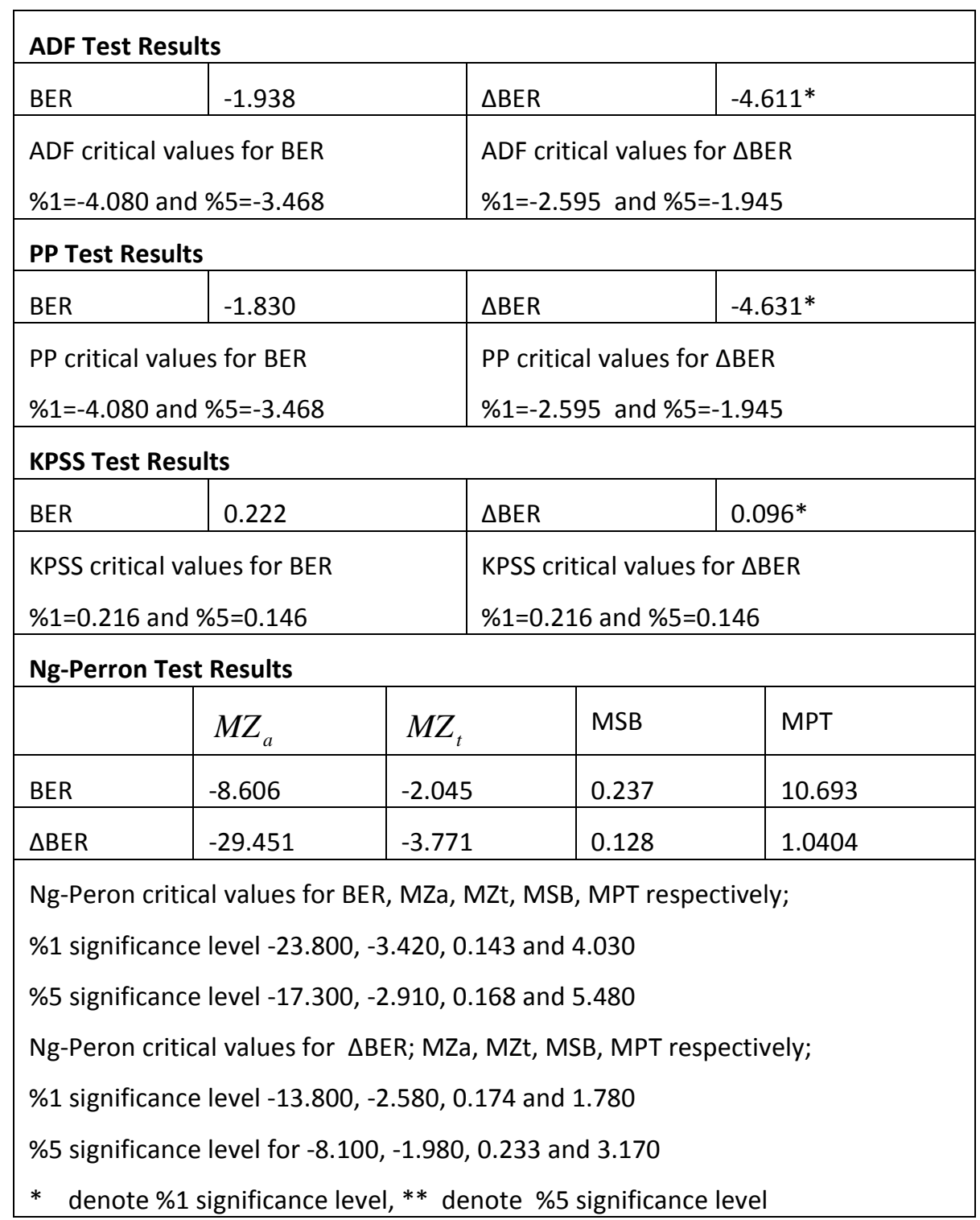


According to Table 3,

- For both ADF and PP tests, the calculated t statistics for BER is less than the critical values. Thus, the null unit roots hypothesis cannot be rejected, suggesting that BER is non-stationary in their level forms. The results of the first differenced variables show that both the ADF and PP test statistics for the variable is greater than critical values at $1 \%$ levels and the variable is stationary after differenced, suggesting that it is I(1) according to ADF and PP tests

- The calculated $t$ statistics for BER is greater than the critical values in their level forms and the results of the first differenced BER is less than critical values at $1 \%$ levels. KPSS test results suggest that BER is I(1).

- For MZa and MZt tests, the calculated $t$ statistics for the variable is less and for MSB and MPT tests the calculated $t$ statistics for the variable is greater than the critical values suggesting that the variable is non-stationary in their level forms. For the first difference of BER, according to MZa and MZt tests, the calculated $t$ statistics for the variable is greater and for MSB and MPT tests the calculated $t$ statistics for the variable is less than the critical values suggesting that the variable becomes stationary after differencing so that BER is I(1) according to NgPeron tests.

The results of unit root tests with structural breaks are presented in Table 4.

Table 4: Unit Root Tests With Structural Breaks

\begin{tabular}{|c|c|c|c|c|}
\hline \multicolumn{5}{|c|}{ Zivot-Andrews (1992) Test Results } \\
\hline & \multicolumn{2}{|l|}{ Level } & \multicolumn{2}{|c|}{ First Difference } \\
\hline & Model A & Model C & Model A & Model C \\
\hline BER & -3.36 & -3.05 & -6.30 & -6.34 \\
\hline $\begin{array}{l}\text { Critical values } \\
(\% 5)\end{array}$ & -4.80 & -5.08 & -4.80 & -5.08 \\
\hline Break Term & 2009M3 & 2009M3 & 2009M1 & 2009M1 \\
\hline \multicolumn{5}{|c|}{ Lee-Strazitch (2003) Test Results } \\
\hline & \multicolumn{2}{|l|}{ Level } & \multicolumn{2}{|c|}{ First Difference } \\
\hline & Model A & Model C & Model A & Model C \\
\hline BER & -2.29 & -4.41 & -6.85 & -6.97 \\
\hline $\begin{array}{l}\text { Critical values } \\
(\% 5)\end{array}$ & -3.84 & -5.71 & -3.84 & -5.71 \\
\hline
\end{tabular}


- For both Zivot-Andrews (1992) and Lee-Strazicich (2003) tests, the calculated t statistics for BER variable is less than the critical values suggesting that the variable is non-stationary in their level forms. For the first difference of BER variable, the calculated $t$ statistics is greater than the critical values. For both Zivot-Andrews (1992) and Lee-Strazicich (2003) tests suggest that BER is I(1).

\section{SUMMARY AND CONCLUSION}

Trade between China and the U.S. has been growing at a very rapid pace over the past thirty years. However, since China's exports have always been greater than of U.S.exports, trade between U.S. and China has created huge deficits for the U.S. Many economists believe that the Chinese policy of undervaluation of yuan significantly contributes to $U \mathrm{~S}$. trade deficits with China. Because of concern over these deficits, decision makers in the U. S. have questioned China's policy regarding exchange rates. In this paper, in an attempt to answer the question of whether or not the exchange rate is linked with domsestic prices in countries, we analyzed the validity of PPP under two different exchange rate regimes.In so doing, we used both conventional unit root tests (the ADF, PP, KPSS and Ng-Perron) and unit roots tests with structural breaks (Zivot-Andrews and Lee-Strazicich).

The study's two main findings point to the effect of China's exchange rate policy on relationship between the relative price level and the exchange rate. First, we provided evidence that the long-run PPP holds under a system of fixed exchange rate which means that changes in exchange rates equal changes in prices. The result indicates that there is full pass-through of exchange rate changes into prices under this period.

Second, our results confirmed that the managed float of China v. U.S.dollar has created a deviation from the PPP path of exchange rate. As noticed, some studies have claimed that the PPP is more likely to hold in open economies with low inflation ${ }^{[5]}$. Indeed, countries with high inflation generally suffer from an exchange rate instability and constitute a priori good examples of PPP refutation (Drine and Rault, 2003:5). Our findings also support McKinnon and Schnabl (2009) and McKinnon et al. (2009)'s results. According to the conclusions reached in these studies, China should reinstall the fixed exchange regime to regain its control on the conduct of the monetary policy.

\section{ENDNOTES}

[1]The Balassa-Samuelson, the macroeconomic balance framework, the competitiveness of the tradable goods sector, estimated exchange rate equatıons, general equilibrium models.

[2] See Chinn (2006) for a nice overview of the theoretical underpinnings of various RER measures. In this working paper we focus on CPI-based RERs and weighted averages of bilateral exchange rates.

[3] Bilateral exchange rate is calculated using time-varying trade-weights based on Chinese trade flows and CPIs.

[4] See Silvia and Iqbal (2009) for more detail.

[5] Alba and Papell (2007) 


\section{REFERENCES}

- Aizenman, Joshua, (1984), “Modeling Deviations from PPP”, International Economic Review, 23:261-80.

- $\quad$ Alba, J.D. \& Park, D. (2003), “Purchasing power parity in developing countries: multi-period evidence under the current float", World Development, 31(12):20492060.

- Breuer, Janice Boucher (1994) "An Assessment of the Evidence on Purchasing Power Parity". In Estimating Equilibrium Exchange Rates. John Williamson, ed. 245-277, Washington, D.C.: Institute for International Economics.

- Craig, Ben (2005)," The Growing Significance of Purchasing Power Parity", Federal Reserve Bank of Cleveland, ISSN 0428-1276

- Cassel, Gustav, (1918), "Abnormal deviations in international exchanges", The Economic Journal, 28:413-415

- Chinn, Menzie D. (2006), “A Primer on Real Effective Exchange Rates: Determinants, Overvaluation, Trade Flows and Competitive Devaluation", Open Economies Review 17: 115-143

- Dickey, D. A., \& W. A. Fuller. (1981). "Likelihood ratio statistics for autoregressive time series with a unit root", Econometrica, 49 (4): 1057-72.

- Dornbusch, Rudiger, (1985),"Purchasing Power Parity", NBER Working Papers, 1591

- Dornbusch, Rudiger (1992) "Purchasing Power Parity" In The New Palgrave Dictionary of Money and Finance. Peter Newman, Murray Milgate and John Eatwell, eds. Vol. 3, 236-244, New York: The Stockton Press.

- $\quad$ Drine, Imed \& Rault , Christophe, (2003)"A re-examination of the Purchasing Power Parity using non-stationary dynamic panel methods: a comparative approach for developing and developed countries, "William Davidson Institute Working Papers Series 2003-570, William Davidson Institute at the University of Michigan.

- Enders, W. (2004), Applied Econometric Time Series, 2nd ed., John Wiley \& Sons, Inc.

- Gil-Alana, Luis Alberiko and Jiang, Liang (2011)," The Purchasing Power Parity Hypothesis In The Us-China Relationship: Fractional Integration, Time Variation And Data Frequency", International Journal of Finance \& Economics, DOI: 10.1002/ijfe.461 
- Glynn, J., Perera, N.and Verma, R. (2007), "Unit Root Tests and Structural Breaks: A Survey with Applications", Journal of Quantitative Methods for Economics and Business Administration, 3(1): 63-79

- Guo, Q., (2010), “The Balassa-Samuelson model of purchasing power parity and Chinese exchange rates", China Economic Review, 21 (2):334-345.

- Gregory, Richard Paul and Shelley, Gary (2011), "Purchasing Power Parity and the Chinese Yuan", Economics Bulletin, 31 (2):1247-1255

- Gujarati, D.N. (2004), Basic Econometrics.4th ed. McGraw-Hill Inc. New York, USA.

- $\quad$ Kwiatkowski, D., Phillips, P.C.B., Schmidt P. And Shin Y. (1992). "Testing the Null Hypothesis of Stationarity against the Alternative of a Unit Root," Journal of Econometrics, 54, 159-178.

- Lee, J., and MC Strazicich (2003), “Minimum Lagrange multiplier unit root test with two structural breaks", Review of Economics and Statistics, 85:1082-89.

- McKinnon, R., Schnabl, G., (2009). 'The Case for Stabilizing China's Exchange Rate: Setting the Stage for Fiscal Expansion”, China \& World Economy, 17(1), 1-17

- Mussa, Michael (1986), "Nominal Exchange Rate Regimes and the Behavior of Real Exchange Rates: Evidence and Implications", Carnegie-Rochester Conference Series on Public Policy, 25(1):117-214

- Ng, S. and Peron P., (2001), "Lag Length Selection and the Construction of Unit Root Tests with Good Size and Power". Econometrica, 69(6), 1519-1554.

- Darne, Olivier \& Jean-François Hoarau, (2006) "Testing the purchasing power parity in China,"EconomiX Working Papers 2006-18, University of Paris West Nanterre la Défense, EconomiX.

- Perron, P. \& P. C. B. Phillips (1987), "Does GNP have a unit root? Areevaluation”, Economic Letters, 23:139-145.

- $\quad$ Perron, P. \& Vogelsang,T. (1992), “Nonstationarity and shifts with an application to purchasing power parity", Journal of Business and Economic Statistics, 10: 30120

- $\quad$ Rogers, John H and Michael Jenkins, (1995),"Haircuts or hysteresis? Sources of movements in real exchange rates", Journal of International Economics, 38:33960 . 
- Rogoff, K. (1996), "The purchasing power parity puzzle”, Journal of Economic Literature, XXXIV (June) :647-668

- Silvia, J., \&lqbal, A. (2011),"The Empirical Evidence of Mean Diversion in the U.S. Labor Market 1970-2009", International Journal of Economics and Finance, $3(1): 44-55$

- Taylor, M.P. (2003), "Purchasing power parity", Review of International Economics, 11: 436-452

- Waithe Alastair J., (2010), Testing Purchasing Power Parity: A US-China Case Study And A Cross-Country Analysis, Phd Thesis, Brooklyn College, City University of New York

- Yu, Chunjiao and Zhu Longfei (2010)," Testing the validity of the purchasing power parity hypothesis: a study based on the RMB/USD exchange rate", Int. J. of Networking and Virtual Organisations, 7:(4)323 - 334

- Zhou, S. \& Kutan, A.(2011), “Is the Evidence for PPP Reliable?: A Sustainability Exercise in the Stationarity of Real Exchange Rates", Journal of Banking and Finance, 35(9): 2479- 2490, 2011

- $\quad$ Zivot, E. \&D. Andrews, (1992), "Further evidence of great crash, the oil price shock andunit root hypothesis", Journal of Business and Economic Statistics, 10: 251-270. 